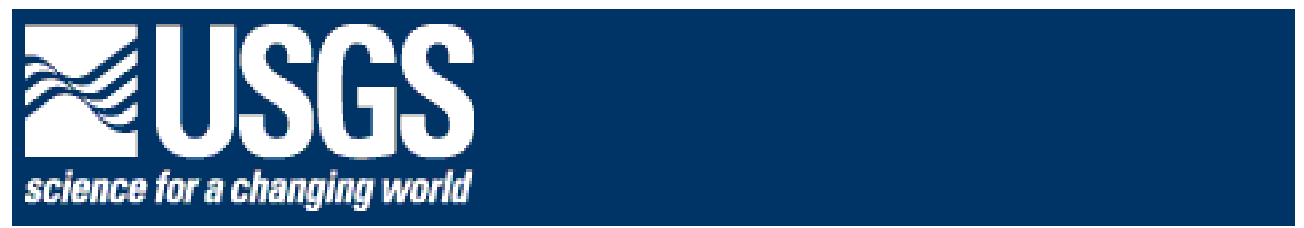

U.S. Geological Survey

Open-File Report 02-221

\title{
Field-Trip Guide to the Geology of the Lexington Reservoir and Loma Prieta Areas in the Santa Cruz Mountains, Santa Clara and Santa Cruz Counties, California
}

\author{
by Phil Stoffer ${ }^{1}$ and Paula Messina ${ }^{2}$
}

2002

\begin{abstract}
This guide contains a road log and five stop descriptions for a field trip in the southern Santa Cruz Mountains. The trip officially begins at the boat dock parking area on Alma Bridge Road near the dam of Lexington Reservoir. Stop 1 involves a walk up the Limekiln Trail to examine a large landslide in serpentinite that frequently takes out the trail. Stop 2 is at Miller Point picnic area along the shore of the reservoir where exposures of massive, fractured graywacke sandstone are capped with terrace gravel deposits. Stop 3 is along Highland Way in the Santa Cruz Mountains where large landslides have occasionally force the closure of the road. Stop 4A-C are several closely spaced outcrop areas along Loma Prieta Avenue and Summit-Mt. Madonna Road in the Loma Prieta summit area. A walk to scenic vista points provide opportunity to discuss the evolution of regional landscape along the crest of the Sierra Azul. In addition, a variety of rock types are exposed in the Stop 4 area along a series of road cuts, including Cretaceous age conglomerate, turbidites (consisting of interbedded sandstone and shale), and fossiliferous mudstone. Stop 5 involves returning to the boat dock parking area to examine geology and the placement of the Lexington Dam in the Los Gatos Creek canyon.
\end{abstract}

${ }^{1}$ U.S. Geological Survey, 345 Middlefield Road, Menlo Park, CA 94025

${ }^{2}$ San José State University, Department of Geology, 321 Duncan Hall, San Jose, CA 95192-0102 


\section{TRAVEL SCHEDULE}

Arrival and departure times may vary depending of circumstance and weather. ("** Means there are restroom facilities - albeit primitive.)

Some field-trip participants can gather at the loading dock at Duncan Hall on San Jose State University campus*. Leave at 9:00am. The loading dock drive is just west of the 7th Street Parking Garage on San Salvador Street. Day parking is available in the 7th Street Parking Garage at the current price of $\$ 2$ per day, and parking is generally available on weekends.

\section{Arrive at 9:30 - Trip Starting Point - Boat dock parking area on Lexington Reservoir*}

All field-trip participant's should plan to meet at the Lexington Reservoir boat dock parking area. To get to the starting point from San Jose, take Highway 17 south to the Bear Creek Exit. Cross the overpass and return on Highway 17 North a quarter mile to the Alma Bridge Road exit.

Follow Alma Bridge Road across Lexington Dam, and the boat dock parking area is on the right east of the Dam. There are restroom facilities at this location. This is a fee area that requires a $\$ 4$ day use permit that can be purchased from a vending machine in the parking area. However, free parking is also available along the road and by the dam, but the parking lot is a patrolled area. $\mathrm{Be}$ prepared to be moving at 9:30am to join the rest of the vehicles in route from SJSU.

Arrive at 9:45am at Stop 1 - Limekiln Trail Head. Leave at 11:20am.

Arrive at 11:30am: Stop 2 - Miller Point Picnic Area*. Leave at 12:15pm.

Arrive at 1:00pm: Stop 3 - Highland Way landslide hazard area. Leave at 1:30pm.

Arrive at 1:45pm: Stop 4 - Loma Prieta summit area. Leave at 3:30pm.

Arrive at 4:00pm: Stop 5 - Lexington Reservoir boat dock parking area*. Leave at 4:30pm.

PLEASE DRIVE CAUTIOUSLY! Some hills are steep, and portions of the road and bridges are narrow. Drivers, please don't be distracted by discussion in the car. Be aware that the roads in the Santa Cruz Mountains are popular with bicyclists and sports-car enthusiasts. Watch out for drunk, distracted or disoriented drivers!

Also be aware that many of the hillsides along trails are thick with poison oak, and rattlesnakes and ticks can be found practically anywhere in the Santa Cruz Mountains. 


\section{Road Log}

Fig. 1 is a map showing the field trip route. Although the road log begins at San Jose State University, the trip will officially begin at the Lexington Reservoir boat dock parking area.

\section{MILEAGE/NOTES}

0.0 From the Duncan Hall loading dock, turn right on San Salvador Street, then turn left on 4th Street (south).

0.5 Proceed onto the on ramp to I-280 North. (Use caution; be prepared to move over a couple lanes toward the center to avoid a rapidly approaching "exit only" ramp.)

3.0 Take the exit for Highway 17 South toward Santa Cruz.

6.0 On the west (right) side of Highway 17 South between Camden Avenue and Highway 85 are a number of artificial percolation ponds along Los Gatos Creek. A heavily used bike path follow Los Gatos Creek beginning near San Jose City College extending all the way to Lexington Reservoir Dam. South of Highway 85 the bike path follows the shore of Vasona Reservoir (not visible from Highway 17). Lexington Reservoir, Vasona Reservoir, and the percolation ponds are all part of the Santa Clara Valley Water District system to control flooding and to provide water recharge to the aquifer beneath western Santa Clara Valley.

8.0 Highway 17 crosses the interchange with Highway 85.

11.0 Highway 17 enters Los Gatos Creek canyon. Numerous landslides can be seen along the highway and across the canyon. Discussion of the geology of this area is included in the Stop 5 discussion.

12.5 Approximately 1.5 miles above the entrance to the canyon is the James J. Leniham Dam, [better known as Lexington Dam], the dam for Lexington Reservoir. The dam was renamed the James J. Lenihan Dam in 1997 to honor a former director of the Santa Clara Valley Water District. Two small communities, Lexington and Alma, existed in the upper, broad valley of Los Gatos Creek before the reservoir was constructed. The dam and reservoir were completed in 1952.

13.3 Exit Highway 17 at Bear Creek Road Exit. At the top of the ramp turn right and cross the overpass toward the reservoir.

13.4 Turn left onto the north-bound ramp onto Highway 17. Stay in the right lane.

14.6 Turn right on Alma Bridge Road. 
14.9 Cross the spillway bridge on the dam.

15.0 Turn right into the boat dock parking area.

\section{GATHERING PLACE - Lexington Reservoir boat dock parking area (This is also Stop 5).}

This is an alternate gathering point for trip participants. Restroom facilities are available here. This area has a significant amount of foot traffic and is patrolled. Cars can be safely left here for the day (but do not leave valuables in the car). A $\$ 4$ park day use pass is required, and can be purchased from a vending machine in the parking lot. A brief introduction to the trip will take place here.

\section{MILEAGE/NOTES}

15.0 From the parking area, turn right on Alma Bridge Road.

15.3 A closed road to Lexington Quarry is on the left. This is one of the larger, active quarries in the Bay Area. The chief product is aggregate (sandstone) used for construction.

15.4 The road crosses a causeway across Limekiln Creek

15.5 Park at the trail head for the Limekiln Trail. Parking for approximately a dozen cars is available on either side of the road.

STOP 1 - Limekiln Trail. (See the Stop 1 discussion below.)

This stop involves a 0.3 mile walk up the Limekiln trail to examine outcrops, vegetation, and a landslide that frequently closes the trail.

\section{MILEAGE/NOTES}

15.5 Continue south on Alma Bridge Road following the shoreline of Lexington Reservoir.

\subsection{Turn right into the Miller Point Picnic Area.}

STOP 2 - Miller Point Picnic Area. (See Stop 2 discussion below.)

This is both a field-trip stop and lunch stop. A short walk down to the shore provides an opportunity to look at massive fractured graywacke outcrops overlain by terrace gravel deposits.

** Please note ** - Individuals who didn't pack a lunch can purchase supplies along route to the next stop at the Summit Center shopping area on Summit Road (see mile 28.1 discussion below). The most direct route to the next stop is as follows. 


\section{MILEAGE/NOTES}

15.7 Turn left out of the Miller Point Picnic Area parking lot. Retrace the route back across the dam.

16. 8 Return north on Highway 17 (toward Los Gatos).

18.3 Exit left into downtown Los Gatos.

18.5 Conduct a U-turn where it is both safe and legal.

18.7 Return south on Highway 17.

20.0 Pass Bear Creek Road overpass.

20.5 CDF Fire Department and Heliport are on the left. This facility is a significant command post for fire fighting in the Santa Cruz Mountains. CDF uses helicopters to scoop water from Lexington Reservoir as a means for fire fighting in the rugged terrain in the Santa Cruz Mountains. A significant fire burned much of the hillsides along the east side of Lexington Reservoir in 1985 and threatened or damaged homes in the hills. The mostly chaparral-covered hills were more forested before the fire. The new vegetation is now a significant fire hazard during the dry summer-fall fire season.

23.9 A large artificial retaining wall is on the right. The cement has been textured to appear "more natural." Large landslides from the 1989 Loma Prieta Earthquake closed Highway 17 in this area, creating significant hardship for commuters along the San Jose/Santa Cruz corridor while the highway was repaired. The main trace of the San Andreas Fault probably crosses Highway 17 in this vicinity, however, it did not rupture at the surface in this area during the 1989 Loma Prieta Earthquake. Images of the earthquake damage along Highway 17 and along Summit Road can be seen on a USGS website:

$<\underline{\text { http://geopubs.wr.usgs.gov/dds/dds-29/> }}$

24.3 Turn right onto the Summit Road exit. Turn right at the top of the ramp and cross the overpass bridge. At the stop sign bear left onto Summit Road (heading east).

24.4 Mountain Charlie Road is on the left. This area is called Patchen Pass, a low divide along the ridge crest of the Santa Cruz Mountains. An early trail crossed this area in the late Eighteenth Century connecting Mission Santa Clara with Mission Santa Cruz (probably following existing Native American trails). As mining, lumbering, and other regional commerce grew, the need for a road across the mountains lead to the establishment of the Santa Cruz Turnpike Company which, in turn, awarded a road-building contract in 1858 to one of the early white settlers in the area, Mountain Charlie McKiernan. This road roughly ran parallel to the modern Highway 17, and still exists as part of Mountain 
Charlie Road (which intersects Summit Road east of Highway 17). The name Patchen comes from an original settlement located near the summit. The Patchen Post Office, named for a famous racehorse, was located in this vicinity from 1872 to the $1920 \mathrm{~s}$. (Sources: http://www.santacruzpl.org/history/work/edtranrd.shtml and http://www.mountaincharlie1850.org/historytour.html).

25.0 Considerable damage occurred in this area from the 1989 Loma Prieta Earthquake. Large fissures and slumps took out Summit Road in numerous places, and most homes and buildings sustained moderate to heavy damage, or were destroyed. At least one fissure about a half mile east of Highway 17 displayed evidence of right-lateral offset, consistent with the interpretation of right-lateral displacement along the San Andreas Fault. However, the epicenter of the Loma Prieta Earthquake was several miles to the south and east in the undeveloped land within the Forest of Nicene Marks (see Fig. 1).

25.5 Intersection of Summit Road with Old Santa Cruz Highway. The trace of the San Andreas Fault is not clearly defined in this area. Most of the offset of the 1906 earthquake occurred north of this area. Geologists have debated whether the Loma Prieta Earthquake actually occurred on the main trace of the San Andreas Fault. It has been suggested that the main shock may have been on the Zayente Fault, or an unnamed or undetermined fault without a clear surface rupture pattern. After the 1989 Loma Prieta Earthquake, surface ruptures and fissures were found mapped in numerous places in the vicinity. Most fissures were associated with great slumps along the hillsides. However, the trace of the San Andreas Fault through this area can be inferred from landscape features, particularly a system of straight valleys that roughly follow the trace of the fault.

27.2 The footbridge overpass at the Loma Prieta Home Study School. Several schools were heavily damaged or destroyed in this area by the 1906 San Francisco Earthquake and again by the 1989 Loma Prieta Earthquake.

28.1 Summit Center, a small shopping area, is on the left. This mall can provide a potential restroom break or quick food stop in an emergency (not scheduled).

28.3 Intersection of Old San Jose Road (Soquel) with Summit Road. Summit Road is also named Summit-Montgomery Road in this section. Whatever the name, the road basically follows the trace of the San Andreas Fault.

29.7 Burrell Forest Fire Center (sits within jumping distance of the main trace of the San Andreas Fault). The fire center sits on a stream divide along the San Andreas rift valley between Laurel Creek (to the west) and Soquel Creek (to the east).

30.1 Intersection of Summit with Mt. Bache Road and Highland Way. Bear right on Highland Way (the street sign only says Highland). More hummochy landscape and linear ridges in this vicinity highlight the effects of faulting and landsliding in this area. 
33.0 Park along Highland Way in the vicinity of the large landslide where it is "safe."

STOP 3 - Highland Way landslide area. (See Stop 3 discussion below.)

This stop is to examine bedrock exposures of sandstone and shale exposed in a massive landslide escarpment and to view the forested landscape in the area. The Soquel State Demonstration Forest is on the south side of the rift valley of the San Andreas Fault (defined here by Soquel Creek).

\section{MILEAGE/NOTES}

\subsection{Return west on Highland Way.}

36.1 Turn right on Mt. Bache Road. (Be cautious on this road. It is narrow in places, and drivers coming down hill may not be expecting on-coming traffic.)

37.1 Loma Prieta Road comes in on the left. Mt. Bache Road becomes Loma Prieta Avenue [although it is not labeled such]. Continue uphill on the paved road (Loma Prieta Avenue). There are numerous pricey homes in this area.

$38+\quad$ Turbidites (interbedded sandstone and shale) occur in road cuts all along this section of the road.

39.5 Park on the right in a parking area lined with large boulders next to power lines with 3 wooden poles. Do not block the gate for the fire trail.

STOP 4A - Loma Prieta upland area. (See Stop 4A discussion below.)

Next to the pull-off is a short, steep trail to a excellent viewing area on the small hill top. Exceptional views of Santa Cruz County and the Monterey Bay region are possible here. The valley to the right is the rift valley of the San Andreas Fault. Exposures of marine mudstone and shale can be examined in the area.

39.6 Numerous parking areas exist along the road where it crosses a saddle in the ridge. Park anywhere near the small hill on the left near the center of this saddle in the ridge.

STOP 4B - Loma Prieta upland area. (See Stop 4B discussion below.)

Loma Prieta Peak is clearly visible on the left beyond the headwaters valley of Los Gatos Creek. Sandstone, conglomerate, and fossiliferous mudstone are exposed in road cuts and outcrops on the small hill near the middle of the saddle area (see Stop 4 discussions).

39.7+ More interbedded sandstone and shale (turbidites) exposed in road cuts on the right. 
40.1 Intersection of Loma Prieta Avenue and Mt. Madonna-Summit Road. Park in the large parking area on the right near this intersection.

STOP 4C - Loma Prieta upland area continued. (See Stop 4B discussion below.)

This stop entails a walk to examine sandstone, shale, and conglomerate outcrops, landslides, and vistas of the Santa Clara Valley from along Mt. Madonna-Summit Road. Serpentinite outcrops can be seen on the flanks of Loma Prieta.

Return to vehicles and drive north (in the direction we came).

\section{MILEAGE/NOTES}

0.0 Reset mileage to 0.0. Drive north (downhill) on Loma Prieta Avenue (or Summit-Mt. Bache Road).

3.0 Intersection of Mt. Bache Road with Summit-Montgomery Road. Bear right on Summit.

8.7 Intersection of Summit Road with Highway 17. Bear right on Highway 17 north.

13.3 Exit right on Alma Bridge Road (returning toward Lexington Dam).

13.7 Turn right into the boat dock parking area.

STOP 5 - Lexington Dam in Los Gatos Creek canyon. (See Stop 5 discussion below.)

This final stop involves a walk down the Los Gatos Creek Trail to examine cliff exposures of sepentinite and graywacke sandstone, and to evaluate the placement of the Lexington Reservoir Dam in its current location. Faults and landslide in this area will also be examined.

\section{End of field trip.}




\section{Stop Descriptions}

\section{Stop 1 - Limekiln Trail}

This stop involves a quarter-mile walk to a landslide that frequently closes the Limekiln Trail. Rocks exposed throughout the hillsides are part of the Franciscan Assemblage (fig. 2). The Franciscan consists of a mix of rock types formed in a variety of geologic settings including ocean crust and sub crustal igneous and metamorphic rocks, and sediments and volcanic materials deposited in environments ranging from the deep-ocean basin to continental rise and shelf settings. These rocks were brought together by the processes associated with subduction and continental accretion. Rocks of the Franciscan are Early Jurassic to Late Cretaceous in age (roughly 180 to 65 million years), but have undergone continuous alteration since then. Younger Tertiary and Quaternary sediments are also incorporated into the mix of Earth materials brought together by faulting and other processes associated with the formation of the Santa Cruz Mountains.

Between the parking area and the landslide, rock outcrops along the trail consist of highly fractured mudstone, graywacke sandstone, and metabasalt. The landslide occurs in deeply weathered and fractured serpentinite adjacent to a fault (fig. 3). Stream washed blocks and boulders of serpentinite are abundant in an intermittent stream that flows past the toe of the slide area (figs. 4 and 5). The dominant minerals in the serpentinite include glaucophane (a blue, high-grade metamorphic variety of serpentine mineral), antigorite (a more common earthy-green serpentine mineral), and lesser amounts of lizardite (a soft, white to green, scaly-textured serpentine mineral). Other minerals associated with the serpentinite include chrysotile (a fibrous variety of asbestos) and brucite (a magnesium-oxide mineral). Other rocks that can be found in the vicinity include chert (both sedimentary and metamorphic varieties, including the reddish-orange variety called jasper), metasandstone, metabasalt, slate, and some limestone and dolostone.

The variety of rock found in the landslide area reflects the complex geologic character and history of the Santa Cruz Mountains. Serpentinite is formed from the metamorphic alteration of ultramafic rock derived from ocean crustal rocks or the mantle. The serpentine mineral glaucophane is thought to form in a deep crustal setting (such as in a subduction zone). Sedimentary chert forms from radiolarian ooze deposited in a deep ocean setting. Graywacke sandstone and mudstone forms from marine sediments derived from volcanoes and other terrestrial sources, and limestone and dolostone forms from the alteration of calcareous mud deposited in relatively warm, shallow, tropical, clear water settings (such on a guyot [submarine volcano] or shallow marine platform). The juncture of these different rock types is related both ancient and ongoing faulting in the region. Prior to about 30 million years, the geologic setting of the region was a subduction zone along the western margin of the North American continent (as shown in fig. 1). Starting about 30 million years ago, changing plate configurations along the western margin of the North American plate lead to the end of subduction and initiated the gradual evolution of the San Andreas Fault System. 
The Limekiln Trail follows the valley of Limekiln Creek. Approximately a mile south of the landslide on the opposite side of the valley is the Lexington Quarry, a large active quarry where rock (mostly metasandstone) is mined and processed into aggregate for construction. Geologic maps of the area show a system of southeast-trending faults through the area. One large fault mapped in this area, the Limekiln Fault, basically follows the trace of the stream valley. The fault exposed along the side of the landslide is only a part of the larger fault system. These faults are part of a system of southeast-trending faults that splay from the main trace of the San Andreas Fault. The main trace of the San Andreas Fault traverses the hills on the southern and western side of Lexington Reservoir. Other earthquake faults nearby include the Berrocal, Monte Vista, and Sargent Faults that traverse the foothills through Saratoga, Los Gatos, and across foothills along the eastern flanks of the Sierra Azul and continues onward toward Morgan Hill and Gilroy (see Wagner, 1990).

\section{Stop 2 - Miller Point Picnic Area}

The Miller Point Picnic Area is located on a small peninsula created by the flooding of the Lexington Reservoir. Besides being an excellent place for a picnic, the park offers an opportunity to examine rocks exposed along the reservoir shoreline. Large blocks of graywacke sandstone stand out along the shore. Wave erosion along the high water line along the shore has exposed an ancient stream terrace deposit consisting of a mix of gravel derived from upland localities (fig. 6). Along the shore it is possible to see places where the gravel rests unconformably on an eroded surface of the older bedrock (graywacke). The gravel was deposited along the ancestral Los Gatos Creek. The stream has since carved about 20 meters deeper into the valley since the time the gravel was deposited here.

The gravel contains an assortment of different rock types, with graywacke being the most abundant. Rock types not seen in the Limekiln Trail area include conglomerate and the volcanic rock cobbles that were derived from the conglomerate (fig. 7). The volcanic rocks are dominantly andesite and possibly dacite -- these volcanic rocks are "intermediate" in composition between more felsic rock (granite and rhyolite) and mafic rock (gabbro and basalt). The volcanic cobbles (or clasts) display an abundance of phenocrysts (visible crystal mineral grains) that tend to float in a finer ground mass (fig. 8). In addition, the volcanic rock contains xenoliths (pieces of the original host rock that was intruded by the volcanic material). The occurrences of these clasts in the terrace gravels demonstrate how Earth materials are recycled (formed, eroded, deposited, exposed, eroded, and deposited again, etc.). The conglomerate is derived from outcrops throughout the upper hillsides of the Sierra Azul. It also forms part of the resistant ridge crest on the southwest side of Mt. Umunhum and along the ridge south of Loma Prieta peak, and probably elsewhere under the forest cover. Similar gravel deposits can be found around the parking area at Los Trancos, nearly 20 kilometers to the northwest.

Most of the volcanic cobbles (or clasts) are "rotten" -- they practically crumble in your hands. This is due to chemical weathering of the gravel in the shallow surface environment (processes 
associated with soil development). This weathering characteristic is also a reflection of their antiquity in that modern gravel and cobbles found in the creek bed are much more durable. "Rotten gravel" (called grus) is common on older Pleistocene glacial till and terrace deposits throughout the Rocky Mountains and eastern Sierra Nevada. Although these terrace gravels have no direct relation to glaciation (there is no evidence of glaciation in the Santa Cruz Mountains), the occurrences of terraces along valleys in the region are related to "valley broadening" periods during the Pleistocene. This is opposed to "valley deepening" periods when streams carve downward into their flood plains. During times of high-standing sea level (during interglacial periods), the rise in stream base level tends to allow streams to backfill their channels with sediment. During wetter periods (associated with glaciation), the combined influence of increased stream flow, reduction in sediment supply (due to increased vegetation), and lowered sea level (due to the formation of continental glaciers) induces streams to carve into their flood plains. Incising streams locally leave bench-like, gravel-covered terraces along the valley sides.

The period from fall, 2001 to spring, 2002 was dryer than normal, so water levels were low in Lexington Reservoir. This allowed the sediments in the bottom of the reservoir to be reworked by Los Gatos Creek and its tributaries (fig. 9). The gravel deposits along Los Gatos Creek are analogous to the environmental conditions that originally deposited the gravel now exposed on the hillside terrace.

\section{Stop 3 - Highland Way Landslide Area}

Along Highland Way about three miles west of the intersection of Summit Road are a series of landslides that have frequently closed down the road to through traffic. The road was most recently closed by massive landslides that occurred during the wet fall/winter of 1998 (fig. 10). The road has since been repaired, but the "fresh" landslide escarpments are still visible (although construction repairs have smoothed out the typically chaotic landscape associated with landslides). The steep, forested landscape throughout this region displays abundant evidence of landslide activity -- both active slides and other more ancient slides that are probably dormant.

A combination of factors make this area prone to landslides, including:

long, steep slopes;

bedrock consisting of sedimentary rock (mostly shale and highly fractured sandstone); a seasonally wet period;

mountain climatic conditions that promotes organic activity and associated weathering; rapidly down-cutting streams that undermine slopes;

human activity - particularly their preponderance to cut slopes to build roads; and, frequent landslide trigger mechanisms, including earthquakes and major storms.

Highland Way follows the valley of Soquel Creek which also happens to be the "rift valley" of the San Andreas Fault. Many trees in the Soquel State Demonstration Forest (down the road and 
across the valley) were damaged or fell in the 1989 Loma Prieta Earthquake. The magnitude 7.1 earthquake occurred on Tuesday, 17 October, 1989 at 5:04 p.m. PDT. The mainshock epicenter of that quake was approximately four miles south of the slide area in the heart of the Forest of Nicene Marks State Park at latitude 37 degrees, 02 minutes north, longitude 120 degrees, 53 minutes west. The depth of the mainshock was approximately 11.5 miles below the surface. The fault plane is not vertical, but rather, it dips steeply from the surface at a high angle toward the southwest (NcNutt and Toppozada, 1990). The earthquake produced little physical evidence of right lateral fault trace offset on the surface, however the earthquake initiated numerous slope failures and slump-related ground rupture throughout the Santa Cruz Mountains, particularly along the Summit Road corridor. Near the epicenter uplift of about $55 \mathrm{~cm}$ resulted, whereas east of the fault subsidence occurred in the order of about $15 \mathrm{~cm}$ for the area around Loma Prieta peak. Traveling away from these areas a distance of several miles the measurable relative elevation offset diminishes to being negligible.

The bedrock exposed in the slide area is interbedded white to gray quartz sandstone and gray to black shale of early Tertiary age (Eocene Mt. Madonna Sandstone; probably 55-60 million years). On the west side of Soquel Creek valley the bedrock is a brown mudstone of late Tertiary age (Purisuma Formation; of Pliocene age, about 3 million years). Marine fossils in the Purisuma demonstrate that the Santa Cruz Mountains have risen from below sea level to over 1,000 meters in 3 million years.

\section{Stop 4 - Loma Prieta Uplands}

Other than a few scattered homes and some radio towers, the upland area around Loma Prieta Peak is relatively wild country. The isolated canyons of upper Los Gatos Creek and upper Uvas Creek are prime mountain lion habitat. The west- and south-facing slopes tend to have chaparral to mixed shrub-deciduous forest (particularly bay laurel), whereas the wetter, cooler north- and east- facing slopes are forested with mixed evergreen (spruce-pine-redwoods). Loma Prieta receives the greatest amount of rainfall annually in the South Bay region (on average mixed precipitation equivalent to about 60 inches of rainfall).

The land on and around Loma Prieta peak is privately owned, but basically off limits to development because of natural hazard conditions and lack of utilities. Most of the land north and west of the peak is now part of the Sierra Azul Open Space Preserve (managed by the MidPeninsula Open Space District). However, Loma Prieta Avenue (the southern continuation of Summit Road) provides public access to some of the most spectacular views and scenery in the Bay Area, and an opportunity to observe a variety of geologic features. An excellent resource to the geology of this area is USGS MF 2373: Sheet 3- Loma Prieta Quadrangle: URL: http://wrgis.wr.usgs.gov/map-mf/mf2373/lpmap.pdf $>$. Stop 4 is really three localities within a mile of each other that could be considered walking distance from one another. 


\section{Stop 4A}

At Stop 4A a short, steep walk up a small hill on the south side of the road leads to a sweeping view of all of Monterey Bay to the south, practically a full field of the Santa Cruz urban coastal corridor, and the long, gentle ridge of Ben Lomond Mountain to the west (see figs. 18 and 19). The hilltop stands about 1,000 feet above the slide area on Highland Way (about one quarter mile to the south). Road cuts along Loma Prieta Avenue in this area are Late Cretaceous turbidites, consisting of alternating layers of graywacke sandstone and shale (see fig. 15). Turbidites form from sediment-bearing turbidity currents that roll down the continental slope and spread out on the deep ocean floor. The heavier sand is deposited first (forming sandstone) and the finer silt and clay settle out later (forming mudstone and shale). These deep ocean sediments are now exposed in many areas throughout the Santa Cruz Mountains. In the vicinity of the hilltop overlook, the turbidite sandstone and mudstone cut by the construction of the road now display exceptional examples of spheroidal weathering (the early stages of chemical weathering of freshly fractured rock)(fig. 11).

\section{Stop 4B}

Stop 4B is about 100 meters east of the hill at roadside outcrops. Loma Prieta Avenue follows a ridge crest that parallels the higher Sierra Azul ridge about a mile north (see fig.17). The saddle area also provides exceptional views of the San Andreas Rift Valley to the southwest (see fig. 18). The Sargent Fault basically follows upper Los Gatos Creek that flows in the valley between the ridge with Loma Prieta Avenue and the southern flank of Loma Prieta peak. Like the San Andreas, the Sargent Fault is an active earthquake fault (capable of generating damaging earthquakes). The Sargent Fault splays away from the main trace of the San Andreas Fault close to the intersection of Summit Road and Highway 17, crosses the crest of the Santa Cruz Mountains along the southern side of Loma Prieta peak, and continues southward across the eastern foothills of the Santa Cruz Mountains roughly following the path of upper Uvas Creek towards Gilroy (fig. 21).

Near the center of the "saddle" in the ridge along Loma Prieta Avenue three different kinds of rocks crop out. The first is a massive, highly fractured graywacke sandstone (fig.12). Associated with this sandstone is conglomerate composed of volcanic clasts (andesite and dacite) in a fine sandy matrix and is interpreted as being Late Cretaceous in age (figs.13 and 14). The conglomerate occurs next to a brown fossiliferous mudstone that displays an abundance of oysters and other fossils. This fossiliferous mudstone is possibly of latest Cretaceous or early Tertiary in age. Farther to the south along Loma Prieta Avenue are more road cuts where more turbidites are exposed.

On the north side of the valley of upper Los Gatos Creek on the flanks of Loma Prieta peak are several large, barren outcrops of serpentinite (on the north side of the Sargent Fault). On the dryer flanks of the Santa Cruz Mountains, Pajaro manzanita tends to grow in the areas with 
serpentinite bedrock, whereas chaparral dominates the areas underlain by sandstone. Serpentinite forms the core of the Loma Prieta peak (fig. 16).

\section{Stop 4C}

Stop 4C involves examining road cuts and a view of Santa Clara Valley southeast of the intersection of Loma Prieta Avenue with Mt. Madonna-Summit Road. Turbidites are well exposed in the cuts along the road and the parking area at the intersection of the two roads (see fig. 15). Several hundred feet southeast of the intersection, the turbidites give way to massive conglomerate (seen also at stops 2 and 4B). About one-quarter mile beyond the intersection near a turn out for a driveway, the vegetation has been cleared enough to provide an exceptional view of the Santa Clara Valley, the distant Diablo Range, and the nearby forested headwaters of Uvas Creek (figs. 20 and 21). The radio tower field on Loma Prieta peak and nearby Crystal Peak are also visible, as well as a number of homes that have been built in this high, remote area. This is also a good place to observe the trace of the Sargent Fault where it crosses the western flank of Loma Prieta Peak and descends along the valley of upper Uvas Creek.

\section{Stop 5 - Lexington Reservoir Dam}

This stop involves a walk down the Los Gatos Creek bike trail to examine the placement of the dam and to examine another landslide. The Los Gatos Creek trail system connects the Los Gatos Creek Bike Trail to Alma Bridge Road and includes trails along the creek and along the canyon rim on the east side of the valley.

Lexington Dam was completed in fall, 1952. The 175 foot high, 1,000 foot thick earthen dam was constructed in 34 weeks (fig. 22). The dam was originally called "Windy Point Dam" after a rocky promontory that rose above the southern end of the gorge. The windy character of Windy Point basically vanished with the construction of the massive dam.

Two small communities, Lexington and Alma, were disbanded shortly before construction began on the reservoir. Land between Los Gatos and the reservoir was incorporated into the St. Joseph Hill Open Space Preserve in 1982. Lexington County Park encompasses most of the shoreline around the reservoir.

The geology around the dam site is quite complex. Near the boat dock parking area are massive exposures of graywacke sandstone, whereas a short distance down stream along Los Gatos Creek gorge the bedrock consists of deeply weathered serpentinite that is prone to landsliding (fig. 23). Landsliding can be seen on both sides of the valley where serpentinite crops out. On the north side of Highway 17 an active landslide in the serpentinite continuously dumps material onto the highway (fig. 24). 
A geologic map of the area is available: USGS MF 2373: Sheet 1 - Los Gatos Quadrangle: $<$ http://wrgis.wr.usgs.gov/map-mf/mf2373/lgmap.pdf $>$. This map shows a series of southeasttrending faults crossing the valley in the vicinity of the gorge. These faults basically parallel the main trace of the San Andreas Fault which basically follows the hillsides along the southwest side of Lexington Reservoir and Highway 17 (see fig. 22). On the map, much of the area is labeled "Franciscan melange." Melange is French for "mix" and implies that the bedrock consists of chaotic mix of different lithologies of material ranging from fist- to building-sized blocks in which the individual elements are too small or poorly exposed to map as individual features. Melange implies that the bedrock has experienced a long history of faulting and tectonic activity. 


\section{Selected References}

McLaughlin, R.J., Clark, J.C., Brabb, E.E., Helley, E.J. and Colón, C.J., 2002, Geologic maps and structure sections of the southwestern Santa Clara Valley and southern Santa Cruz Mountains, Santa Clara and Santa Cruz Counties, California. U.S. Geological Survey, Miscellaneous Field Studies 2373, [five digital maps with explanatory links]. Retrieved from the World Wide Web at: < $\underline{\text { http://wrgis.wr.usgs.gov/map-mf/mf2373/> }}$

Links include:

Sheet 1 - Los Gatos Quadrangle: <http://wrgis.wr.usgs.gov/map-mf/mf2373/lgmap.pdf $>$ Sheet 3- Loma Prieta Quadrangle: < $\underline{\text { http://wrgis.wr.usgs.gov/map-mf/mf2373/lpmap.pdf }>}$ Geologic Explanation pamphlet:

$<$ http://geopubs.wr.usgs.gov/map-mf/mf2373/scvexpl.pdf $>$

McNutt, S.R., and Toppozada, T.R., 1990, Seismology of the 17 October 1989 earthquake: California Division of Mines and Geology Special Publication 104, p.11-27.

Nakata, J.K., Meyer, C.E., Wilshire, H.G., Tinsley, J.C., Updegrove, W.S., Peterson, D.M., Ellen, S.D., Haugerud, R.A., McLaughlin,, R.J., Fisher, G.R., and Diggles, M.F., 1999, The October 17, 1989, Loma Prieta, California, Earthquake-Selected Photographs. U.S. Geological Survey, Digital Data Series DDS-29. Retrieved from the World Wide Web at: $<\underline{\text { http://geopubs.wr.usgs.gov/dds/dds-29/>. }}$.

Santa Clara County Parks, 2002, Santa Clara County Parks home page:

$<$ http://www.parkhere.org $>$.

Santa Clara Valley Water District, 2002, Santa Clara Valley Water District home page: $<$ http://www.scvwd.dst.ca.us/>.

Wagner, D.L., 1990, Geologic and tectonic setting of the epicentral area of the Loma Prieta Earthquake, Santa Cruz Mountains, Central California, In McNutt, S.R., and Sydnor, R.H., eds., 1990, The Loma Prieta (Santa Cruz Mountains), California, Earthquake of 17 October, 1989: California Division of Mines and Geology Special Publication 104, p.1-10.

Wentworth, C.M., Clark B.M., Jr., McLaughlin, R.J., and Graymer, R.W., 1998, Preliminary geologic description of the San Jose 30 X 60 minute quadrangle, California: a digital database: U.S. Geological Survey Open-File Report 98-0795. Retrieved from the World Wide Web at: <http://wrgis.wr.usgs.gov/open-file/of98-795/>. 


\section{Figures}

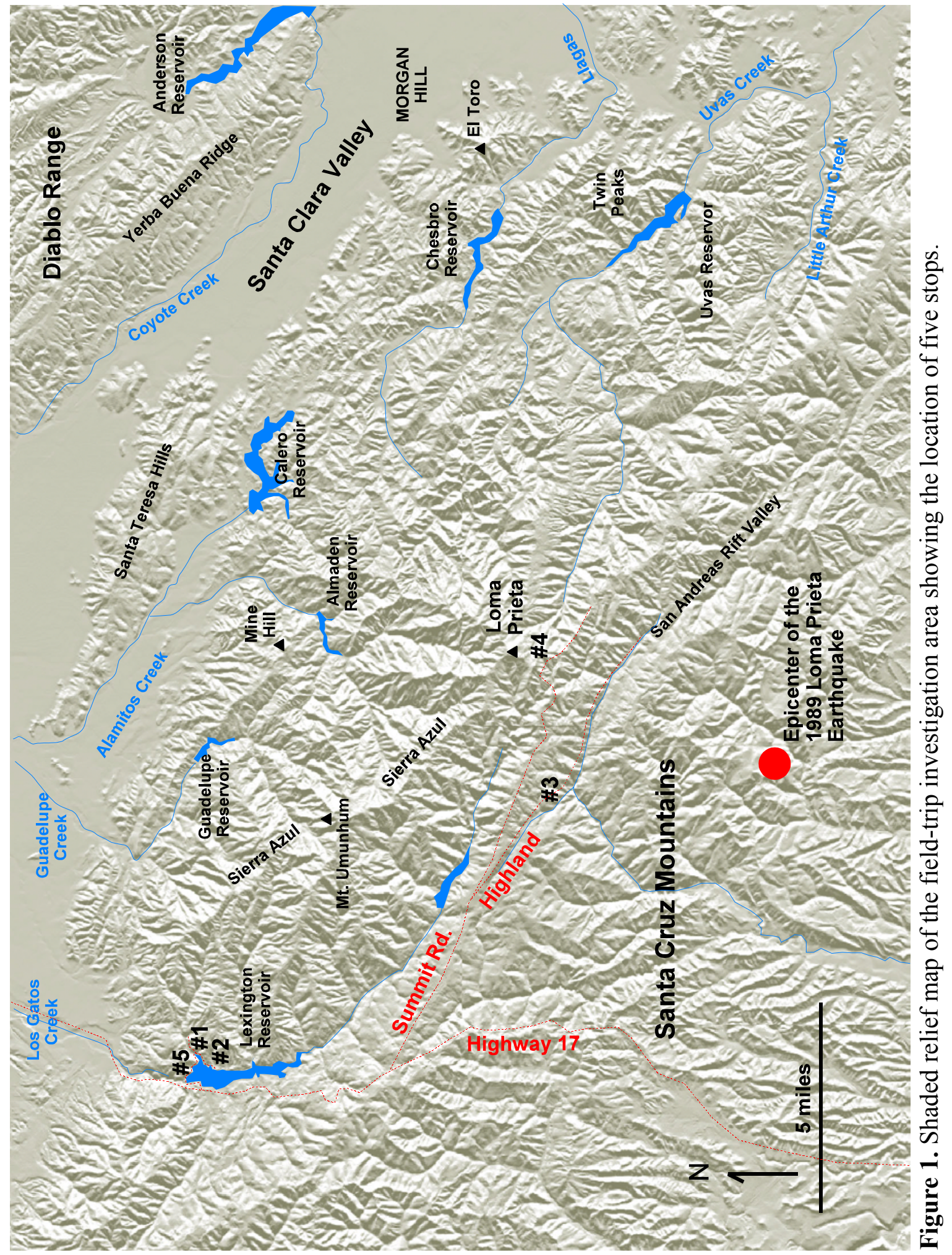




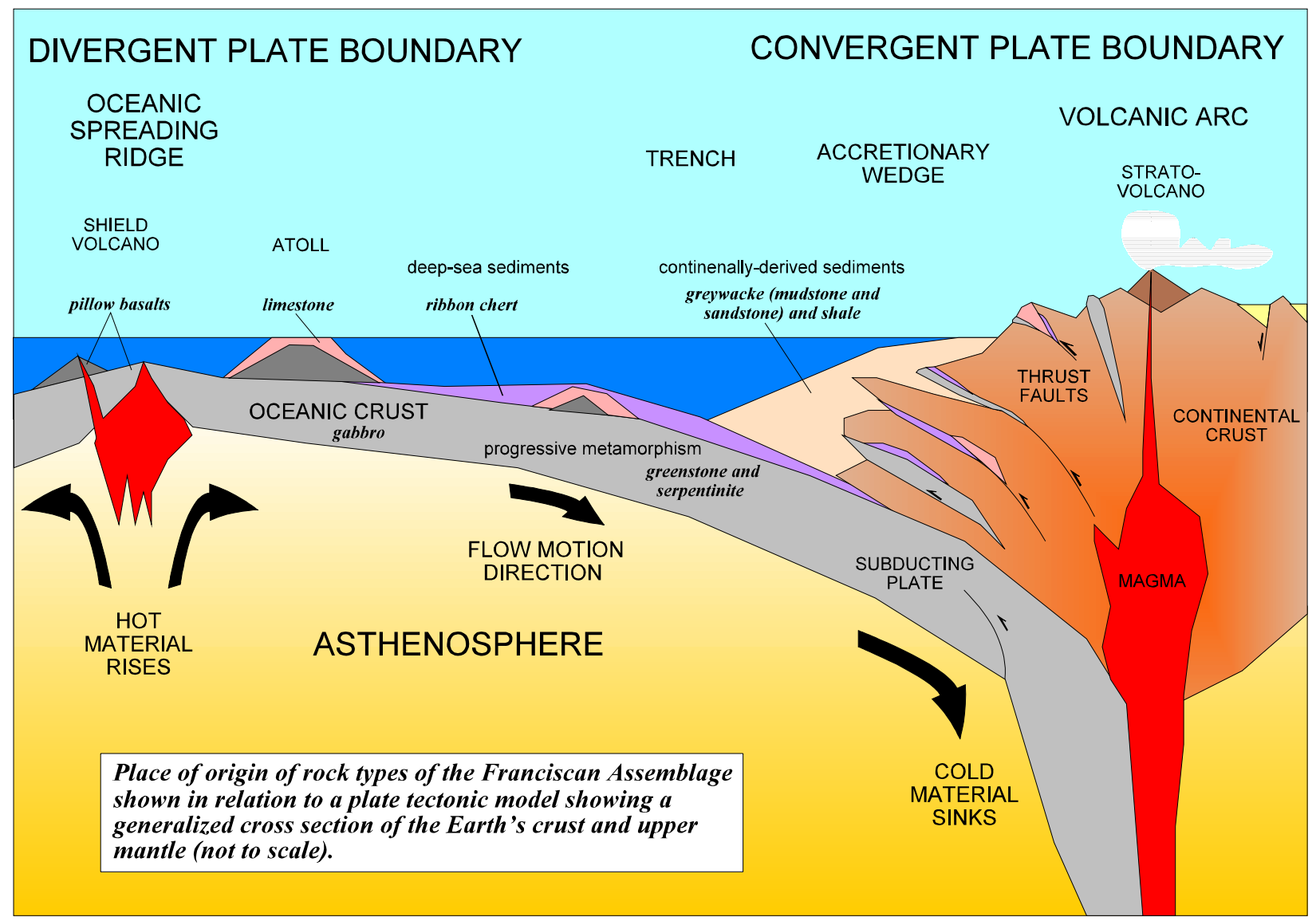

Figure 2. Generalized geologic setting of the western margin of North America showing the origin of different rock materials preserved in the Franciscan Assemblage in the Santa Cruz Mountains. 

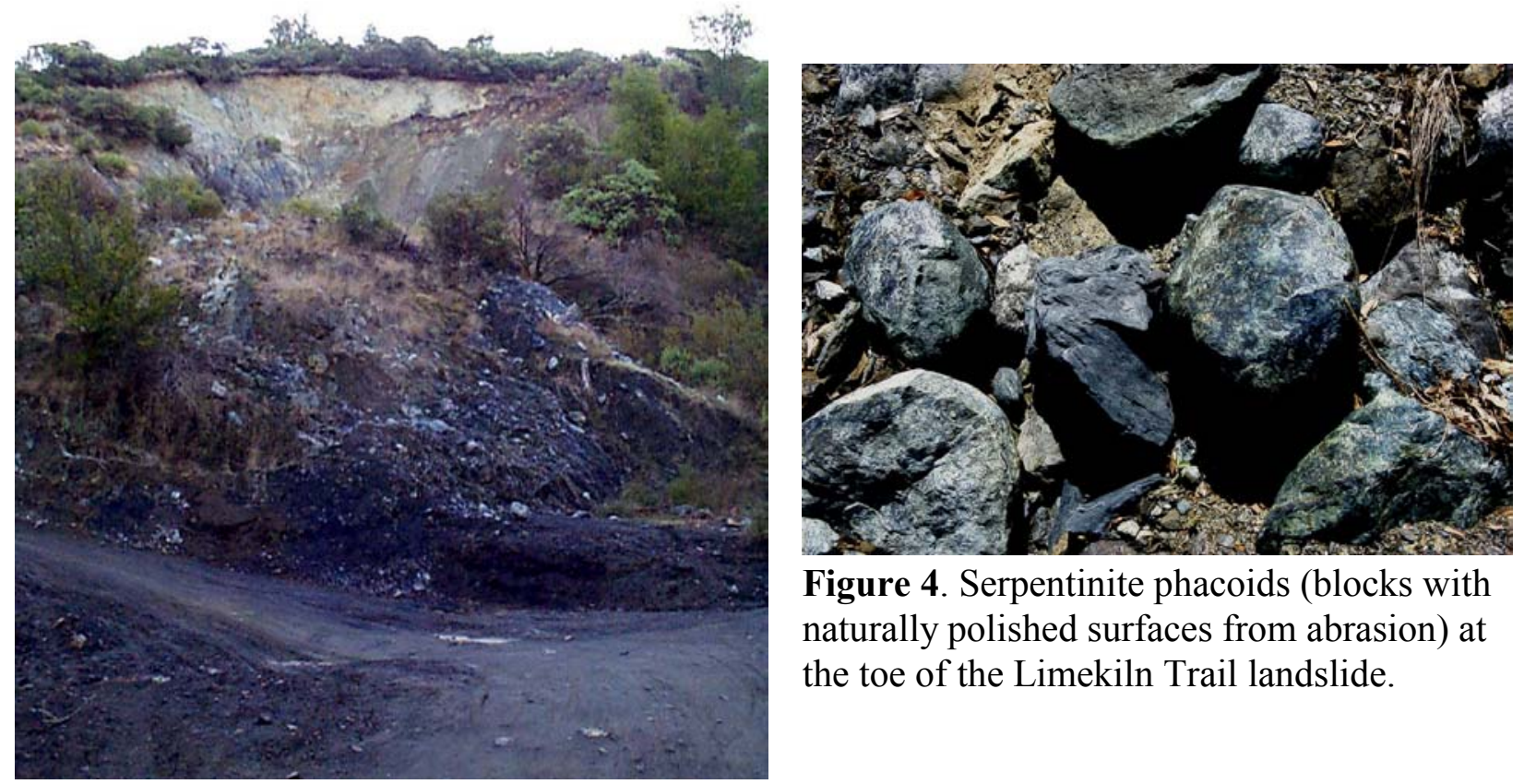

Figure 4. Serpentinite phacoids (blocks with naturally polished surfaces from abrasion) at the toe of the Limekiln Trail landslide.

Figure 3. The Limekiln Trail landslide.

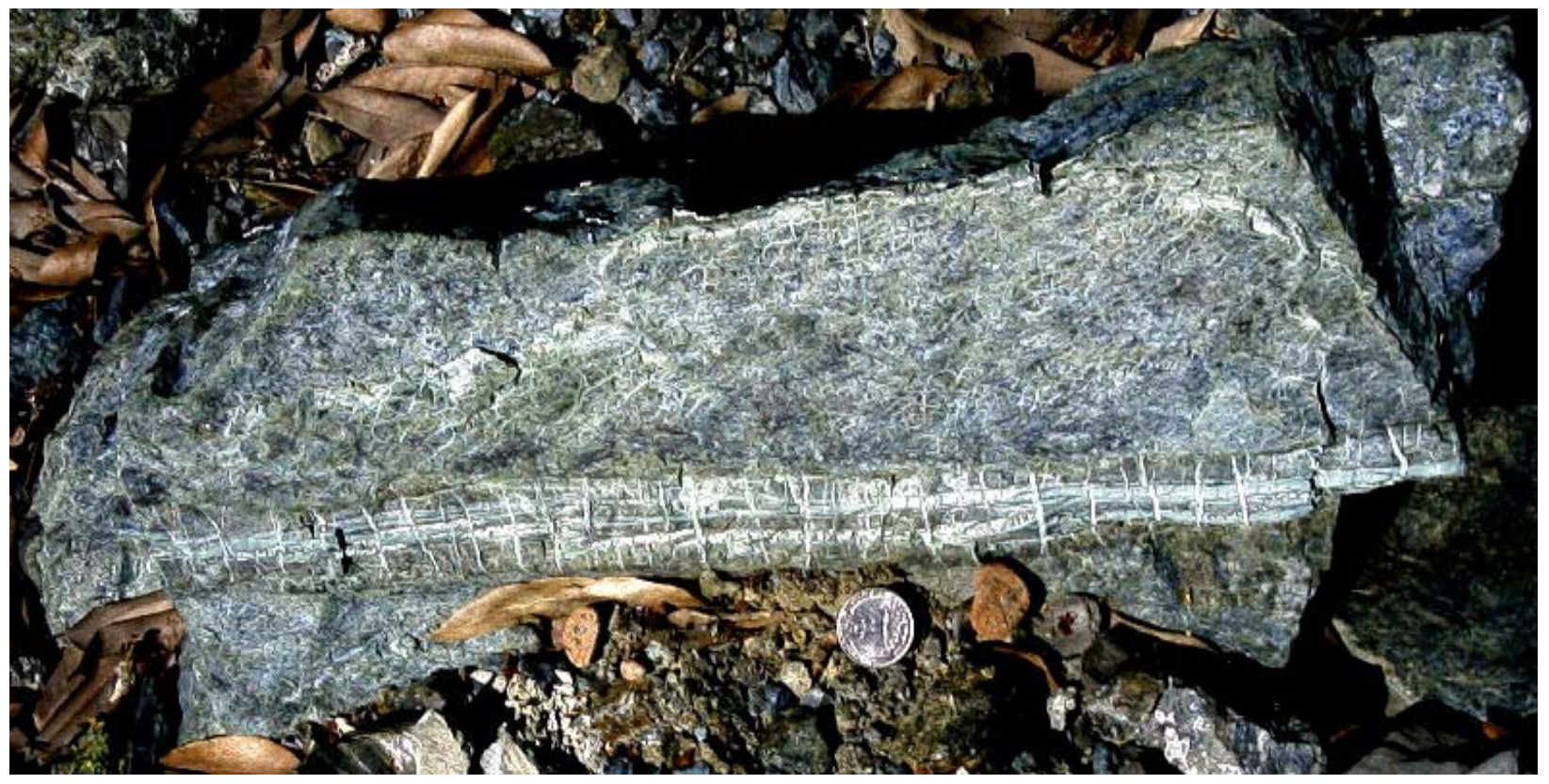

Figure 5. A vein of asbestos in serpentinite (dominant serpentine minerals: glaucophane [blue] and antigorite [green]; the asbestos mineral is chrysotile). 


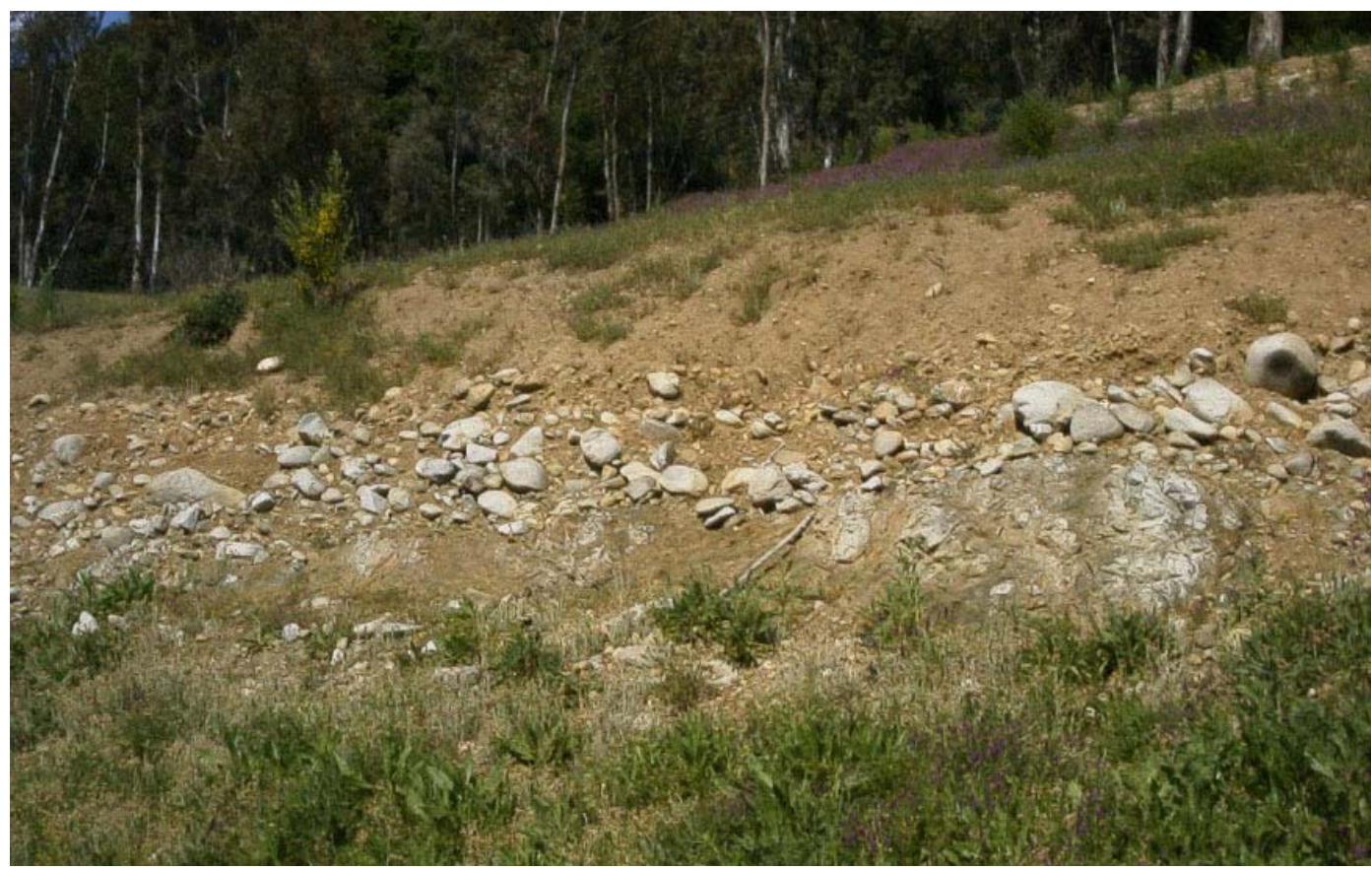

Figure 6. A Pleistocene terrace gravel unconformably rests on an eroded surface of graywacke sandstone. A soil profile has formed in the overlying sediments.

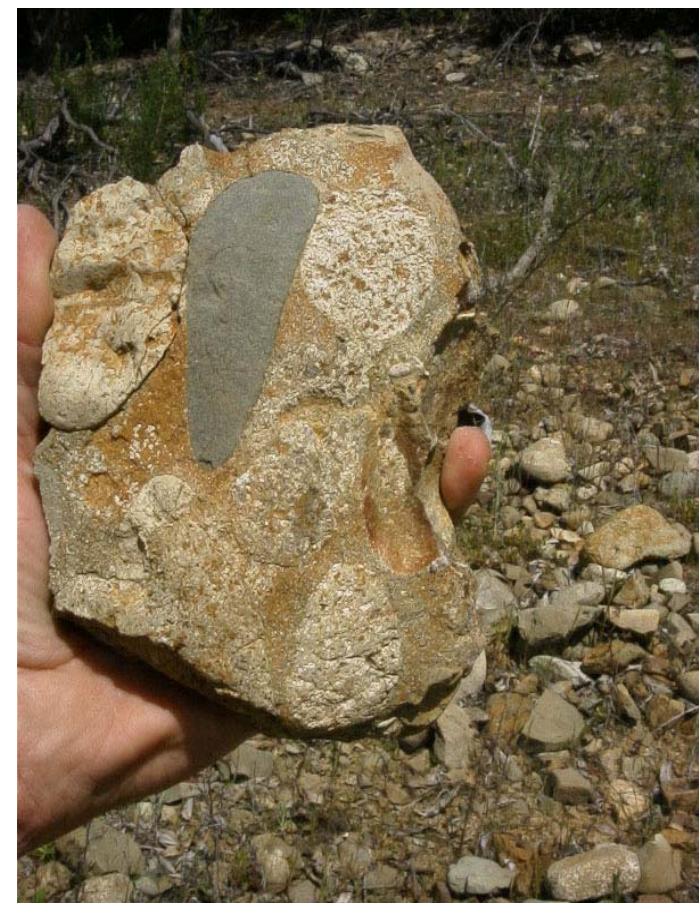

Figure 7. A cobble of conglomerate showing clasts of metasandstone and andesite imbedded in a sandy matrix.

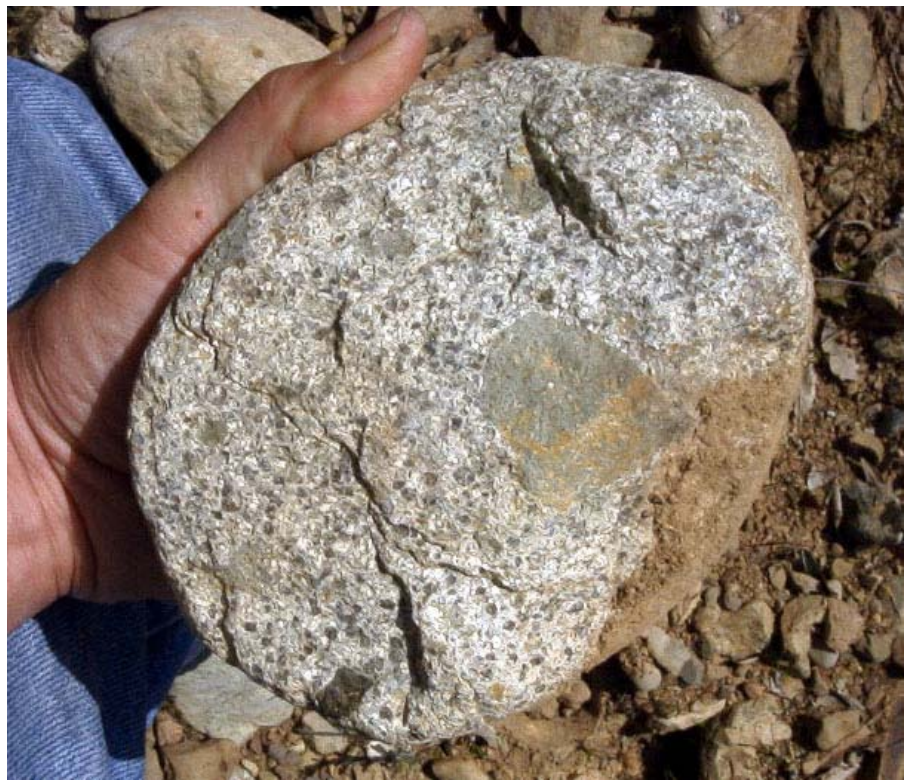

Figure 8. A "rotten" (partial weathered) andesite cobble preserving an inclusion (xenolith) of metasandstone. This cobble was probably derived from the conglomerate. 

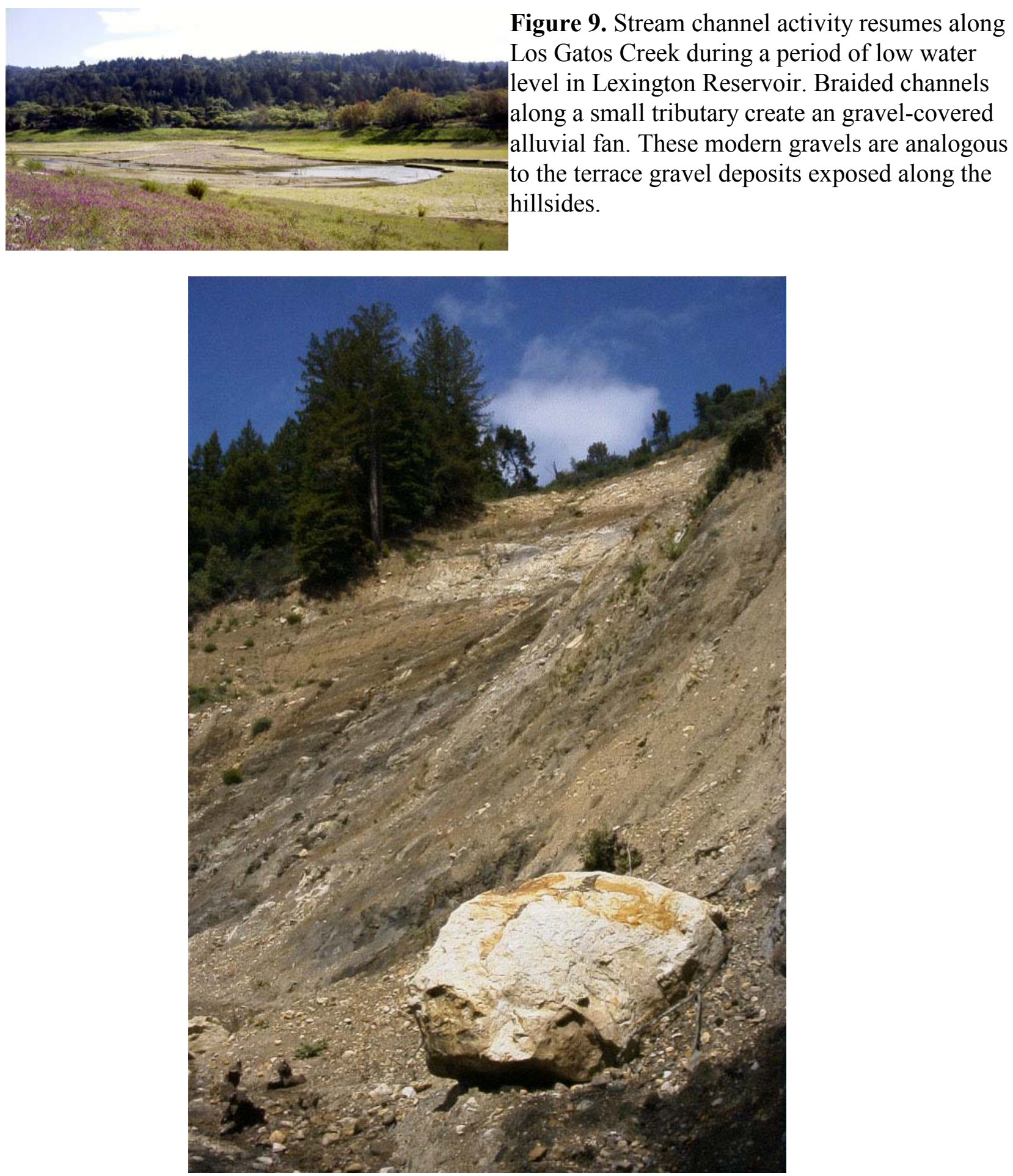

Figure 10. A large sandstone boulder rests "temporarily" on the hillside in the landslide area along Highland Way in the Santa Cruz Mountains. 


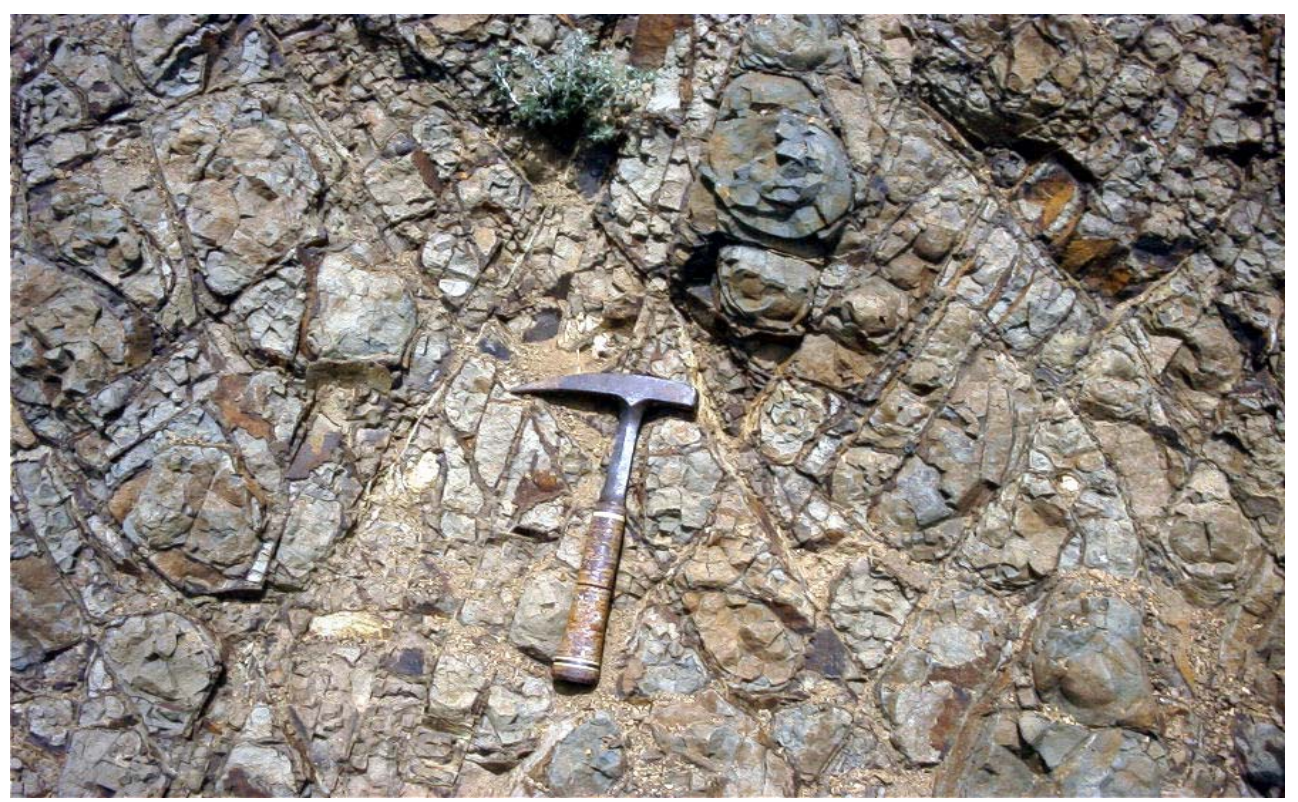

Figure 11. Fractured mudstone exposed in a roadcut along Loma Prieta Avenue at Stop 4A displays "spheroidal weathering" - the early stages the breakdown of rock to form soil. Hammer is about one foot for scale.

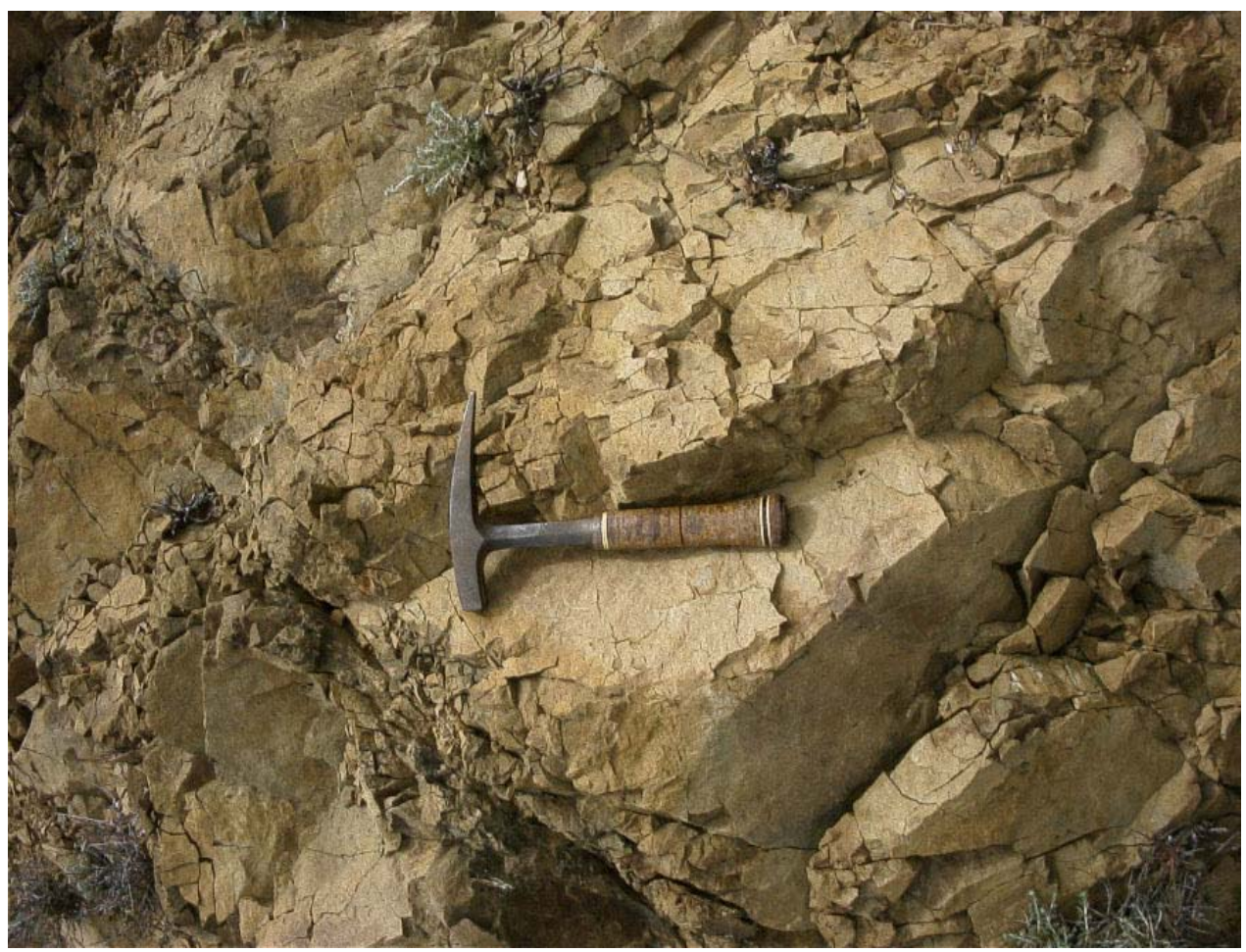

Figure 12. Fractured graywacke sandstone in road cut along Loma Prieta Avenue at Stop 4B. 


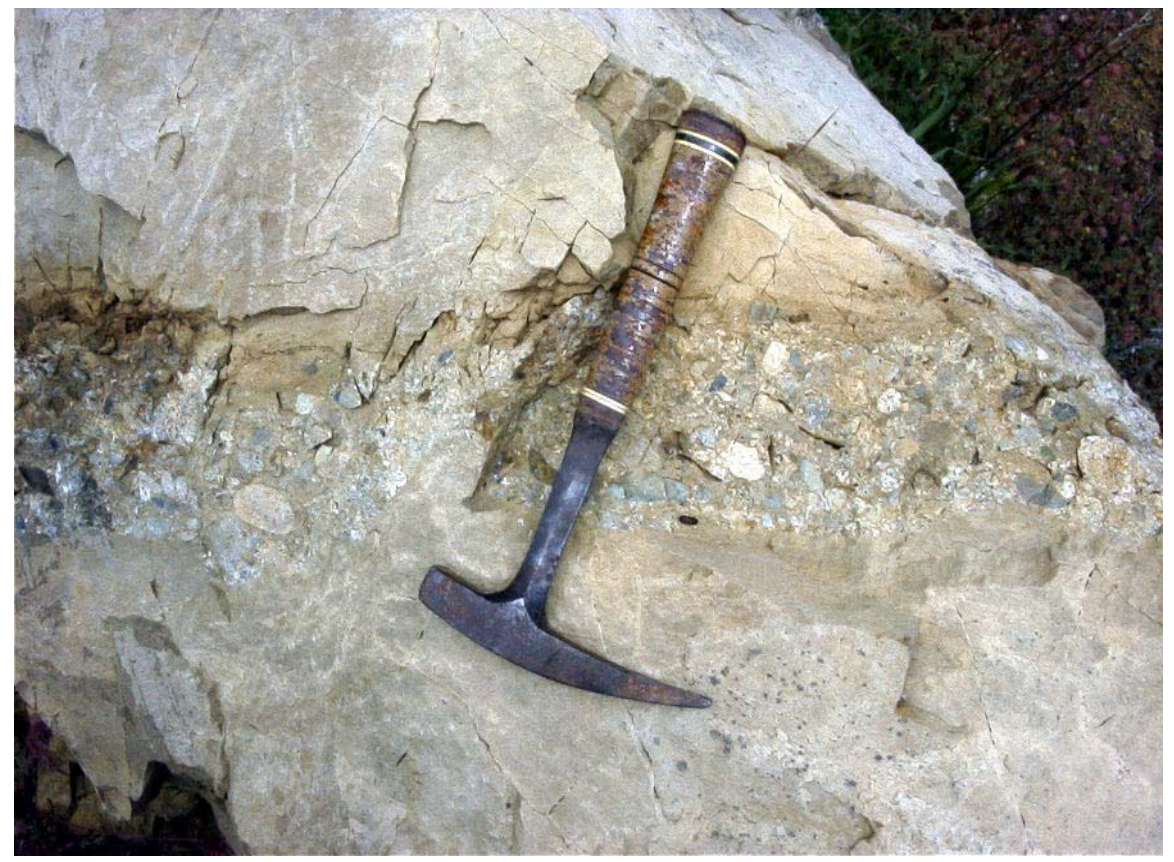

Figure 13. A conglomerate layer between layers of graywacke sandstone along Loma Prieta Avenue at Stop 4B.

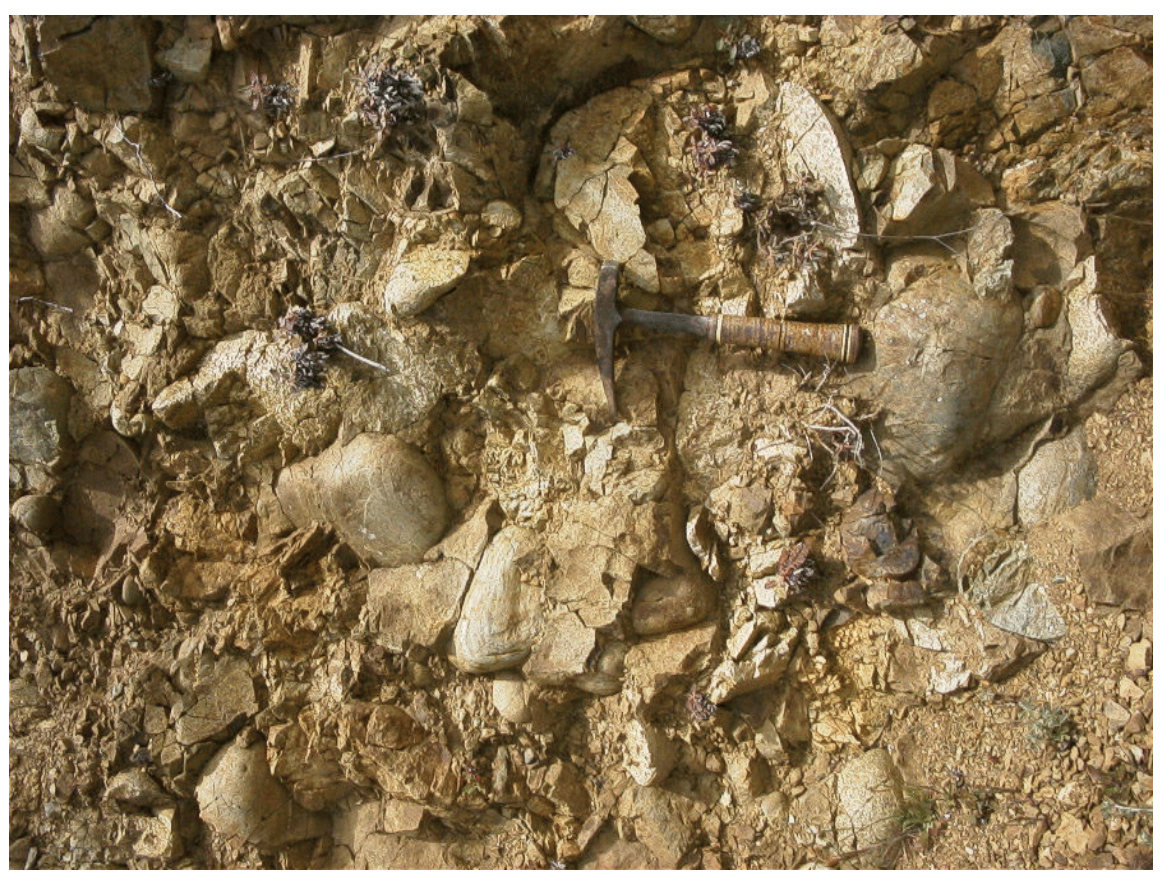

Figure 14. Conglomerate consisting mostly of andesite and dacite cobbles. The outcrop is along Summit-Mt. Madonna Road near Stop $4 \mathrm{C}$. 


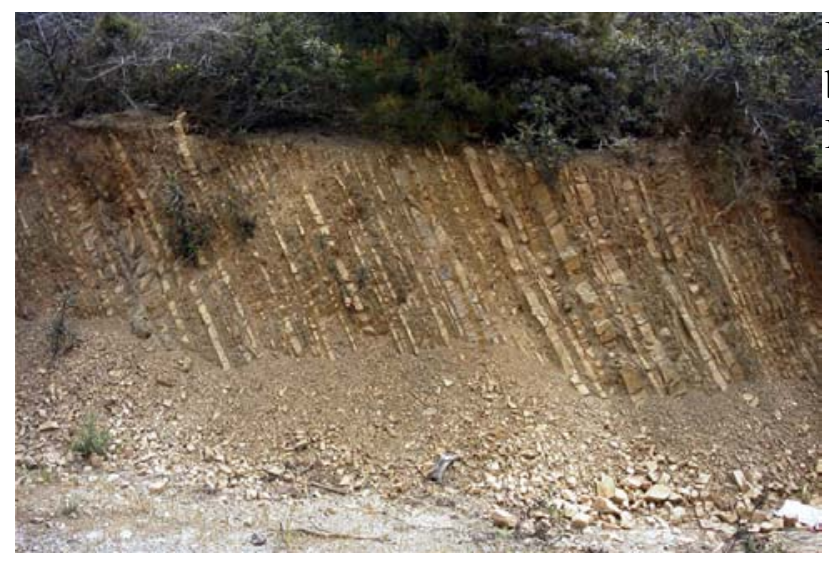

Figure 15. Alternating sandstone and shale beds (turbidites) exposed in a road cut along Loma Prieta Avenue at Stop 4C.

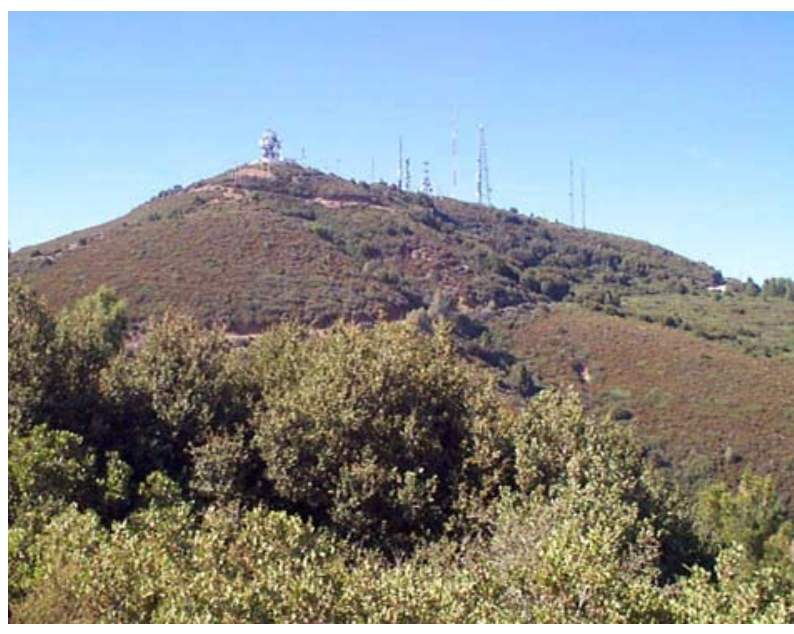

Figure 16. Loma Prieta peak is covered with radio towers, and is off limits to the public. The chaparral covered slopes partially hide the serpentinite bedrock that underlies most of the summit area.

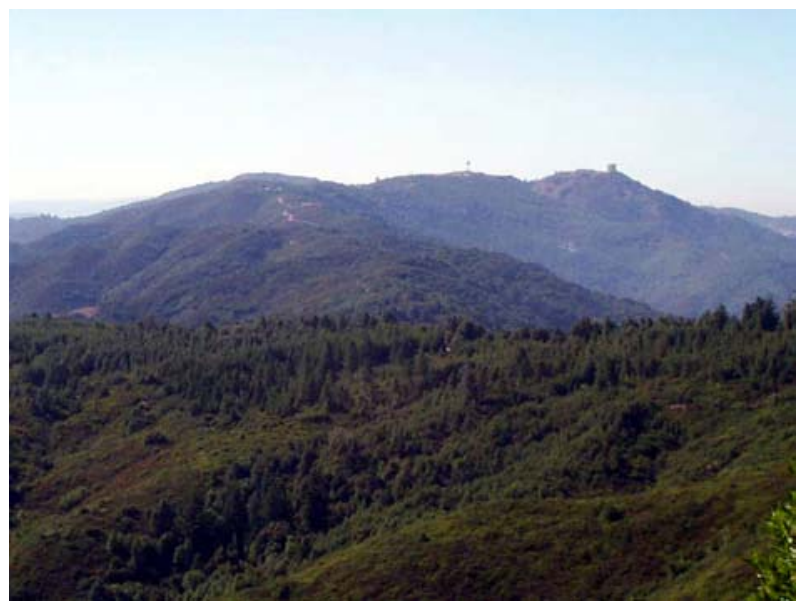

Figure 17. View looking northwest from below the summit of Loma Prieta along the ridge crest of Sierra Azul. The blockhouse on top of Mt. Umunhum is visible on the right. Most of the ridge consists mostly of Cretaceous sandstone, whereas Mt. Umunhum is dominated by Jurassic-age serpentinitized ultramafic rock on its eastern flank (right) and by Cretaceous-age conglomerate on its western flank. 


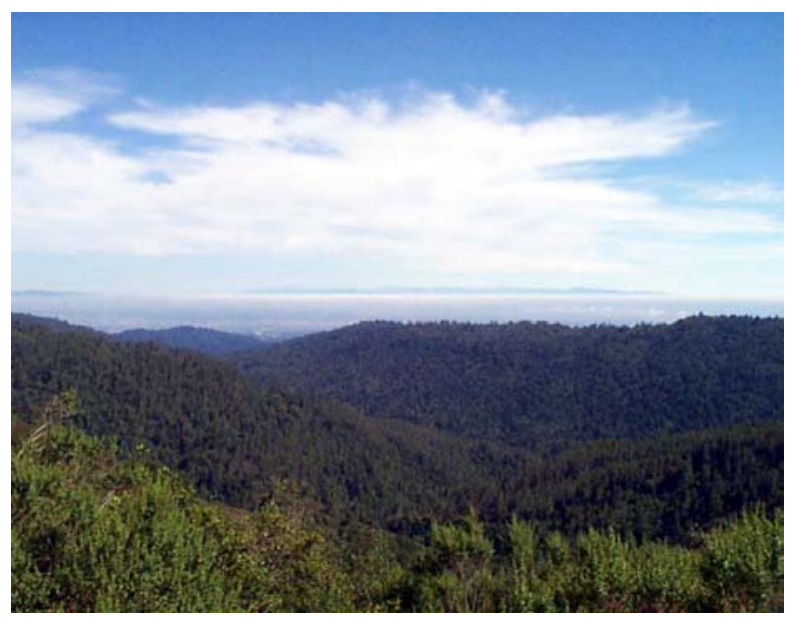

Figure 18. View facing south from Stop 4A of the San Andreas rift valley and the fogcovered Monterey Bay. The Monterey Peninsula is in the distance center, the Gabilan Range to the distant left.

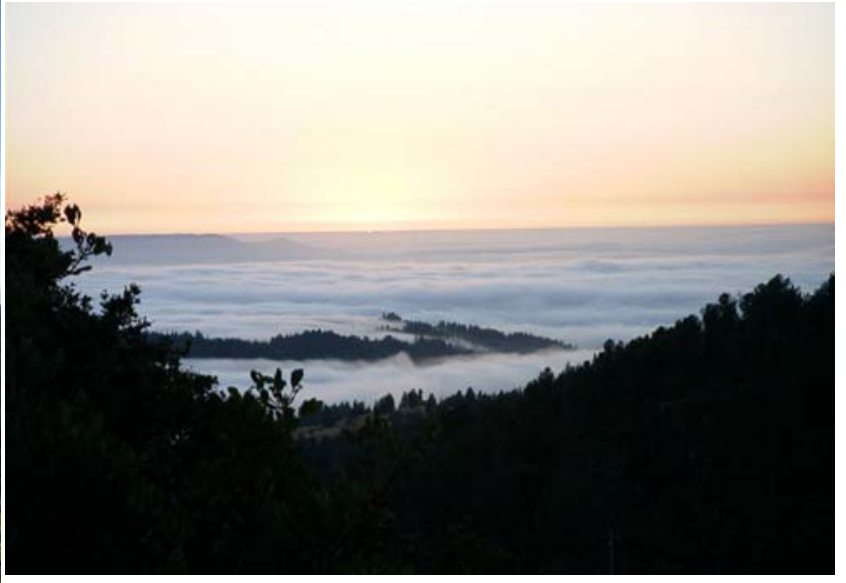

Figure 19. View facing west from Stop 4A of the fog-filled San Lorenzo River valley with the sun setting over Ben Lomond Mountain.

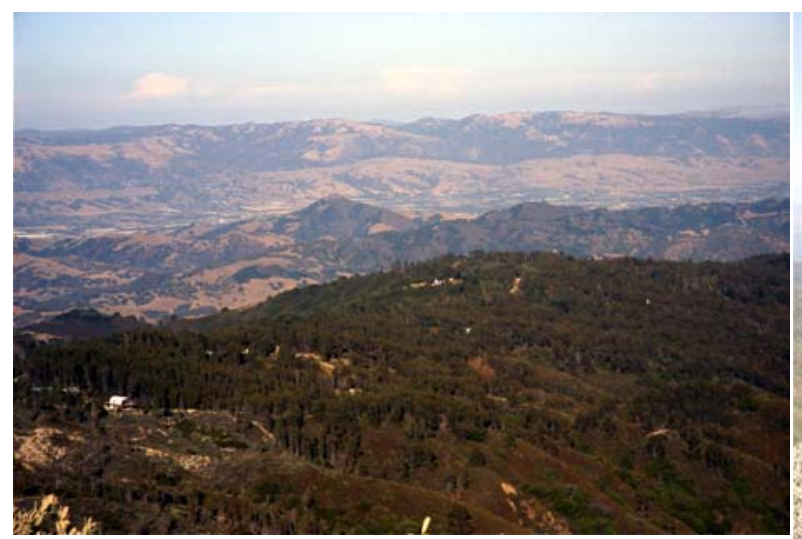

Figure 20. View facing east from Stop 4C overlooking the Santa Clara Valley with El Toro Peak near center and the Diablo Range in the distance.

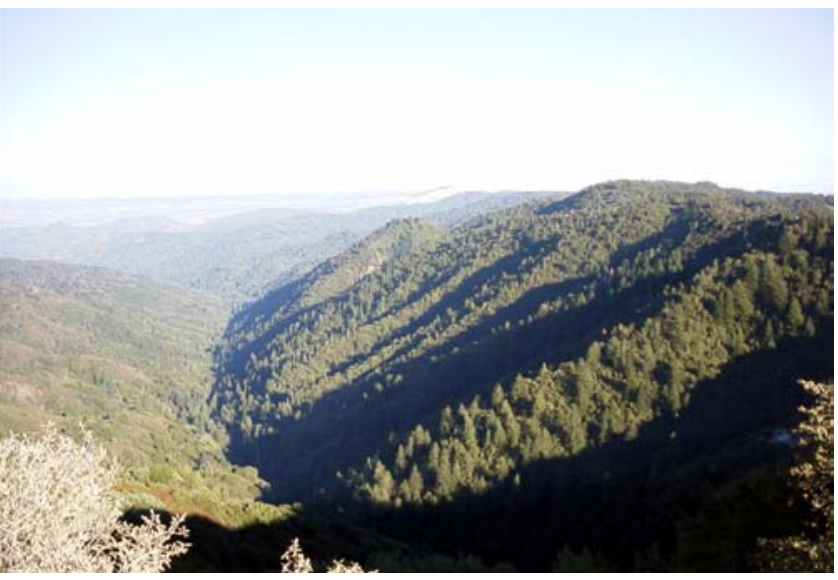

Figure 21. View facing southeast from Stop 4C of the straight valley of upper Uvas Creek (defining the trace of the Sargent Fault). Summit Road follows the ridge on the right. 


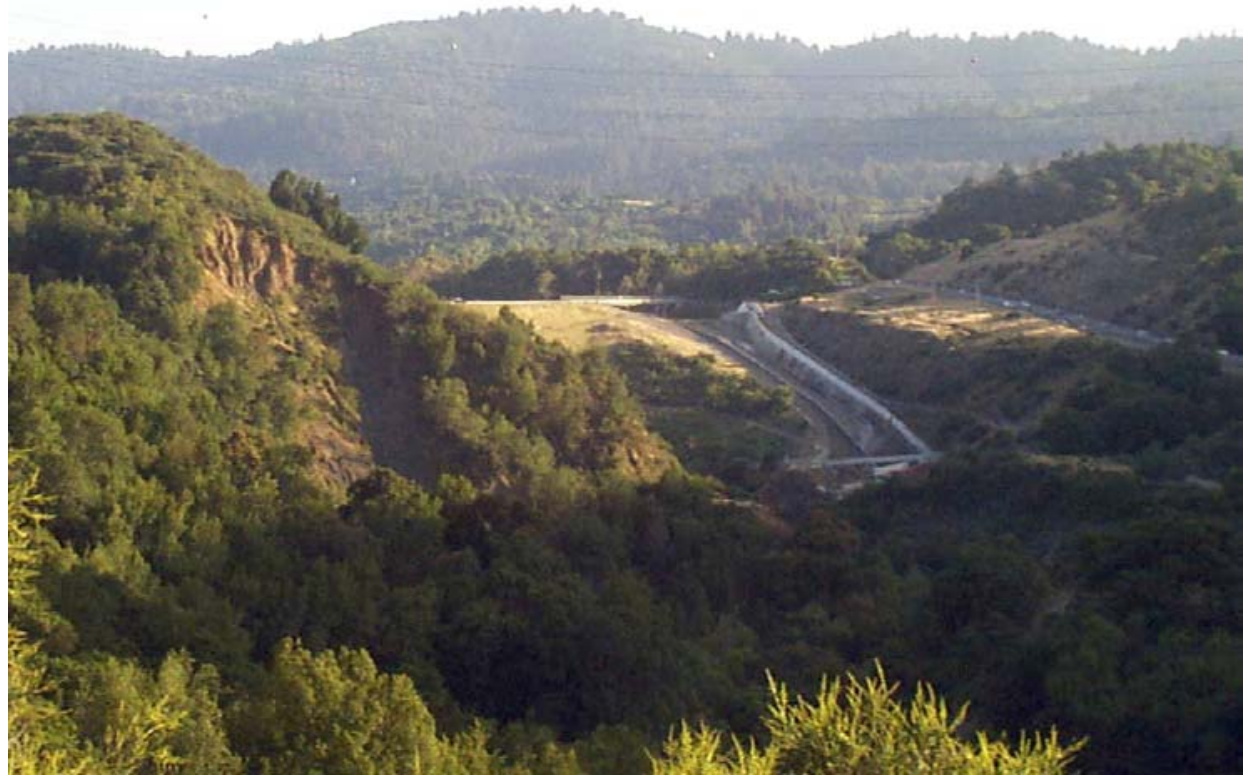

Figure 22. Lexington Dam is sited at the head of a gorge carved by Los Gatos Creek. The valley above the gorge is wider where several tributaries come together. Numerous faults cross the area around Lexington Reservoir including the main trace of the San Andreas Fault that crosses the face of the hills in the distance.

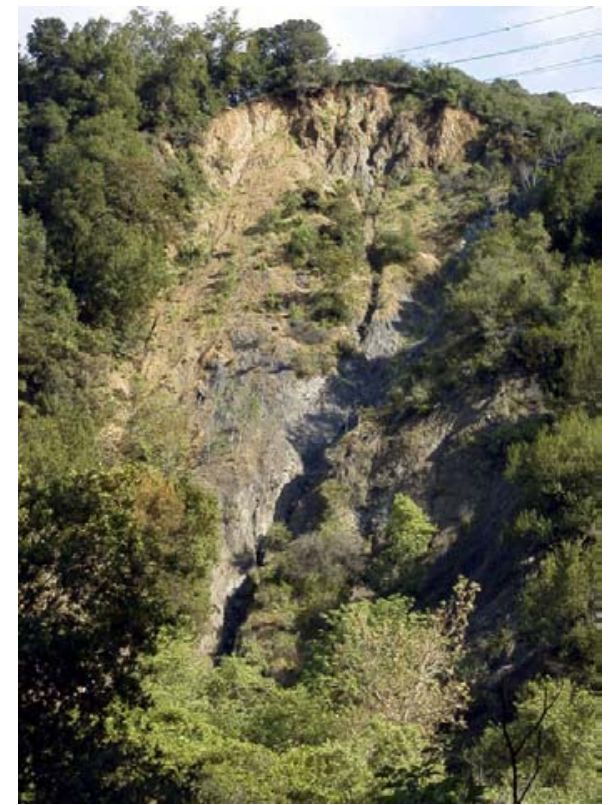

Figure 23. A landslide in

weathered serpentinite below the dam along Los Gatos Creek gorge.

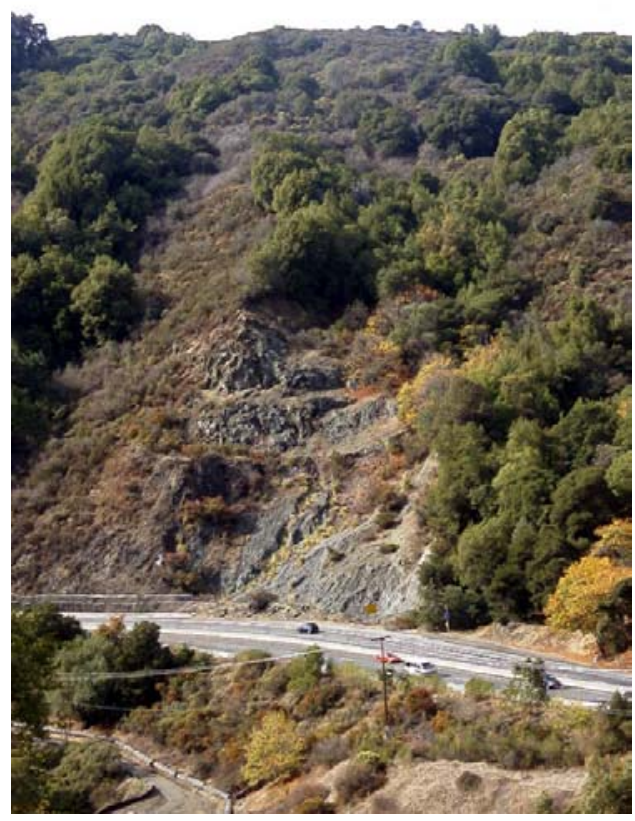

Figure 24. A landslide in weathered serpentinite that affects Highway 17 along Los Gatos Creek gorge. 